ENTREPRENEURSHIP AND SUSTAINABILITY ISSUES

ISSN 2345-0282 (online) http://jssidoi.org/jesi/ 2019 Volume 7 Number 1 (September)

http://doi.org/10.9770/jesi.2019.7.1(30)

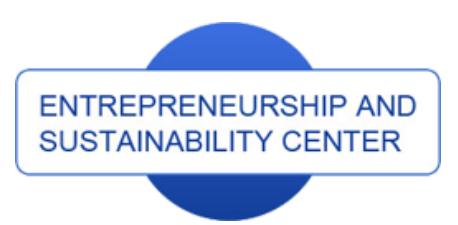

Publisher

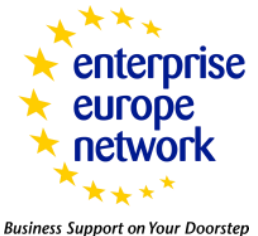

CASPA
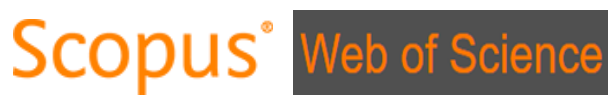

http://jssidoi.org/esc/home

Clarivate
Analytics

\title{
ENTREPRENEURSHIP LEARNING, POSITIVE PSYCHOLOGICAL CAPITAL AND ENTREPRENEUR COMPETENCE OF STUDENTS: A RESEARCH STUDY*
}

\author{
Muhammad Hasan $^{1}$, St. Hatidja ${ }^{2}$, Nurjanna ${ }^{3}$, Feliks Arfid Guampe ${ }^{4}$ Gempita $^{5}$, \\ Muhammad Imam Ma' ruf $^{6}$ \\ ${ }^{1,6}$ Universitas Negeri Makassar, Jl. Raya Pendidikan Kampus UNM Gunung Sari Baru, Makassar, South Sulawesi, \\ Indonesia \\ ${ }^{2}$ STKIP Pembangunan Indonesia, Jl. Inspeksi Kanal No. 10, Kabupaten Gowa, South Sulawesi, Indonesia \\ ${ }^{3}$ STIE Tri Dharma Nusantara Makassar, Jl. Kumala II No. 51, Makassar, South Sulawesi, Indonesia \\ ${ }^{4}$ Universitas Kristen Tentena, Jl. Torulemba No. 21, Kabupaten Poso, Central Sulawesi, Indonesia \\ ${ }^{5}$ STIE Yapman Majene, Jl. Sudirman No. 76, Majene, West Sulawesi, Indonesia \\ E-mail: ${ }^{1 *}$ m.hasan@unm.ac.id (Corresponding author)
}

Received 13 February 2019; accepted 15 July 2019; published 30 September 2019

\begin{abstract}
This study examines the direct and indirect effects of entrepreneurial learning on the formation of positive psychology capital, and explains the direct and indirect effects of entrepreneurial learning and positive psychological capital on student entrepreneurial competencies in Makassar City. This research is included in the type of explanatory research, which is non-experimental. The population in this study were 345 students who had participated in entrepreneurship education and training at state and private universities in South Sulawesi Province, while the sample size was 201 students who already had and were running a business. The results of this study indicate that entrepreneurial learning has a significant effect on the formation of positive psychology capital of students of entrepreneurship, and positive psychology capital has a significant influence on student entrepreneurial competence in South Sulawesi Province. The results of path analysis show that entrepreneurial learning has a significant effect on student entrepreneurial competence through mediation of positive psychology capital.
\end{abstract}

Keywords: entrepreneurship learning; positive psychological capital; entrepreneur competence; students

Reference to this paper should be made as follows: Hasan, M.; Hatidja, St.; Nurjanna, Guampe, F.A.; Gempita, Ma'ruf, M.I. 2019. Entrepreneurship learning, positive psychological capital and entrepreneur competence of students: a research study, Entrepreneurship and Sustainability Issues 7(1): 425-437. http://doi.org/10.9770/jesi.2019.7.1(30)

JEL Classifications: I25

Additional disciplines: psychology; educology

\footnotetext{
* The research was supported by the Directorate of Higher Education and Ministry of Research, Technology and Higher Education, the Republic of Indonesia
} 


\section{ENTREPRENEURSHIP AND SUSTAINABILITY ISSUES}

ISSN 2345-0282 (online) http://jssidoi.org/jesi/

2019 Volume 7 Number 1 (September)

http://doi.org/10.9770/jesi.2019.7.1(30)

\section{Introduction}

In the era of industrial revolution 4.0 which has implications for the importance of economic literacy and digital literacy, every country in the world is expected to be able to have competitiveness, especially in terms of innovation and creativity. However, there are still many countries that face high unemployment rates among their youth, especially young people with low education qualifications (Biavaschi et al., 2012; Hasan \& Azis, 2018; Musa \& Hasan, 2018), so that, mastering science and technology through education and training is one of the determining factors for the success of individual in the workforce (Biavaschi et al., 2012). In an innovation-based digital era, it is necessary to have the well-trained entrepreneurial technical expertise to deal with a rapidly changing global economic environment (Essia, 2012). Thus, there is a need to establish entrepreneurial learning that can form entrepreneurial competencies, especially at the level of higher education (Grubor, 2013; Haeruddin, Pick, \& Thein, in press).

Students need tools, techniques, and theories to help them succeed in finding and directing their world. Some studies have found that entrepreneurship education and business literacy are still lacking among the younger generation, especially the aspects of entrepreneurial knowledge and skills is one of the efforts to improve the economic welfare of young people in the future (Ernst \& Young, 2012).

The results of other studies from Ernst \& Young (2011) confirm that experience in the corporate sector provides an important foundation in business practice. The informants in the study chose experience as employees as having the highest impact (33\%). Higher education is prioritized by almost one third of informants (30\%), followed by mentors $(26 \%)$, families $(21 \%)$, co-founders $(16 \%)$, secondary education $(13 \%)$, colleagues $(12 \%)$, executives $(11 \%)$, friends (9\%), and investors (5\%). Despite having the second highest contribution according to the informants, higher education remains one of the important aspects that is able to provide experience in the formation of entrepreneurial competencies.

Many young people are reluctant to entrepreneurship due to psychological conditions that do not support. Psychological circumstances are valuable personal resources and capital for someone to succeed (Luthans, Luthans, \& Luthans, 2004). Psychological capital is an extension of the concept of "economic capital", but differs from human capital or social capital (Luthans, Luthans, \& Luthans 2004). In other words, psychological capital is the belief that a person has all the mental strength, capacity, and ability to do things for the sake of the progress of oneself and others. Psychological capital is related to "who I am". Psychological capital has four dimensions: selfefficacy, optimism, resilience, and hope (Luthans et al., 2004; Luthans, Avolio, Avey \& Norman, 2007). In various literature, psychological capital is the primary determinant of the success of the entrepreneurial process, including in terms of the formation of entrepreneurial competencies. But in the entrepreneurial literature, more empirical evidence is needed to prove the importance of a positive relationship between psychological capital and entrepreneurial competence (Newman, Schwarz \& Borgia, 2014).

In general, competencies include the knowledge, skills, attitudes, and behaviors needed to complete an activity (Morris et al., 2013). These include strategic thinking, a favorable orientation for change and innovation, the ability to build networks and build strategic alliances, risk assessment, identify opportunities and motivate others around common goals. Mitchelmore and Rowley (2013) propose a structure that establishes six principles of entrepreneurial skills: proper identification and niche market definitions, development of products or services that are in line with niche markets/product innovation, idea creation, environmental identification, recognizing and utilizing opportunities, and formulating strategies to take advantage of opportunities.

Entrepreneurship learning aims to guide all students not only, have an entrepreneurial mindset, but also have the competence and entrepreneurship skills (Hegarty, 2006). At the level of higher education entrepreneurial learning aims to build entrepreneurial spirit and culture, so that students have entrepreneurial intentions and competencies. 


\section{ENTREPRENEURSHIP AND SUSTAINABILITY ISSUES}

ISSN 2345-0282 (online) http://jssidoi.org/jesi/

2019 Volume 7 Number 1 (September)

http://doi.org/10.9770/jesi.2019.7.1(30)

Several studies have been conducted to find out entrepreneurial learning towards the success of students to become successful entrepreneurs. However, findings from several studies are often difficult to observe because there is still a lack of quantity of students who have successful businesses (Amoros \& Bosma, 2014). Seeing these findings, it is felt that there are still research gaps to see the impact of entrepreneurial learning on the formation of student entrepreneurial competencies.

Often, entrepreneurship learning is only related to aspects of knowledge and often neglects the formation of potential skills, abilities, and entrepreneurial attitudes. Therefore, an empirical study is needed to prove the relationship between entrepreneurial learning and the structure of positive psychology capital and entrepreneurial skills in students. Although various learning strategies have been introduced, there is no agreement on the right learning strategies to form entrepreneurial competencies. However, some experts have agreed on three main categories of entrepreneurial learning strategies, which include cognitive plans, meta-cognitive strategies, and resource management strategies (Soric \& Palekcic, 2009; Clayton, Blumberg, \& Auld, 2010).

\section{Literature review}

This article aims to determine the impact of entrepreneurial learning on the formation of entrepreneurial competencies through the formation of positive psychology capital in students, so based on this, the formation of student entrepreneurial competencies includes triggers, processes, and consequences. The trigger for the formation of student entrepreneurial competencies includes beliefs, goals, and contextual embeddedness. The process of developing competencies consists of entrepreneurial learning such as learning by doing (Cope \& Watts 2000; Minniti \& Bygrave, 2001), cognitive learning strategies (Vermetten et al., 1999; Baubonienè et al., 2018), meta-cognitive learning strategies (Huang, 2008), and Clayton, Blumberg, \& Auld (2010) with dimensions of cognitive strategy, meta-cognitive strategies, and resource management strategies.

The consequences of the entrepreneurial process are divided into three categories which include: entrepreneurial competence, entrepreneurial attributes, and entrepreneurial skills (Gibb, 2005). Entrepreneurial behavior includes seeking and utilizing opportunities, taking initiatives to realize things, solving problems creatively, managing independently, being responsible, building networks effectively, arranging things creatively, and being able to take account of various risks. Entrepreneurial attributes of individuals that consist of orientation and ambition of achievement, self-confidence, performance, high locus of control, orientation to action, preference for learning by doing, perseverance, determination and creativity. Entrepreneurial skills consist of creative problem solving, negotiation skills, the ability to manage a business, project or situation holistically, think strategically, and make intuitive decisions under uncertainty. Based on this, the study of this article was based on the assumption that the process of developing entrepreneurial competencies through entrepreneurship learning aims to form entrepreneurial competencies through entrepreneurial attributes of individuals known as positive psychology capital.

Until now, scientists have identified several that determine one's competency in entrepreneurship, including their nature and personality, for example the big five (Ciavarella et al., 2004; Musa, Haeruddin, \& Haeruddin, 2018), the tendency to take risks (Zhao et al., 2005), self-efficacy (Zhao et al., 2005), risks to entrepreneurial activity (Krueger 1993; Matthews \& Moser, 1996), and gender (Marlow \& McAdam, 2011; Haeruddin \& Natsir, 2016; Azis, Haeruddin, \& Azis, 2018). Among these determinants, entrepreneurship learning seems to be one of the important things, because the evidence in previous research shows that there is a clear relationship between entrepreneurial learning and entrepreneurial activity (Henderson \& Robertson, 2000; Galloway \& Keogh, 2006; Girdzijauskaite et al., 2019). 
Psychological tradition in entrepreneurship tends to focus on entrepreneurial description as a phenomenon, not as a way to inform entrepreneurial practice (Frese et al., 2012). This study looks at the psychological aspects of entrepreneurship which are positively related to the formation of entrepreneurial competencies, so that through this, it is possible to design interventions that can improve student entrepreneurial competence through entrepreneurial learning.

Psychological capital is a relatively new concept that is still being developed, especially in the formation of entrepreneurial competencies (Jensen \& Luthans, 2006; Baron et al., 2013). Hmieleski and Carr (2008) found that psychological capital is able to explain the achievement of business performance through the formation of entrepreneurial competencies. Baron et al., (2013) found that entrepreneurs with higher psychological capital have a higher welfare because psychological capital is able to form good entrepreneurial competencies.

Based on the study, the conceptual framework of the process of developing student entrepreneurial competencies can be seen in Figure 1.

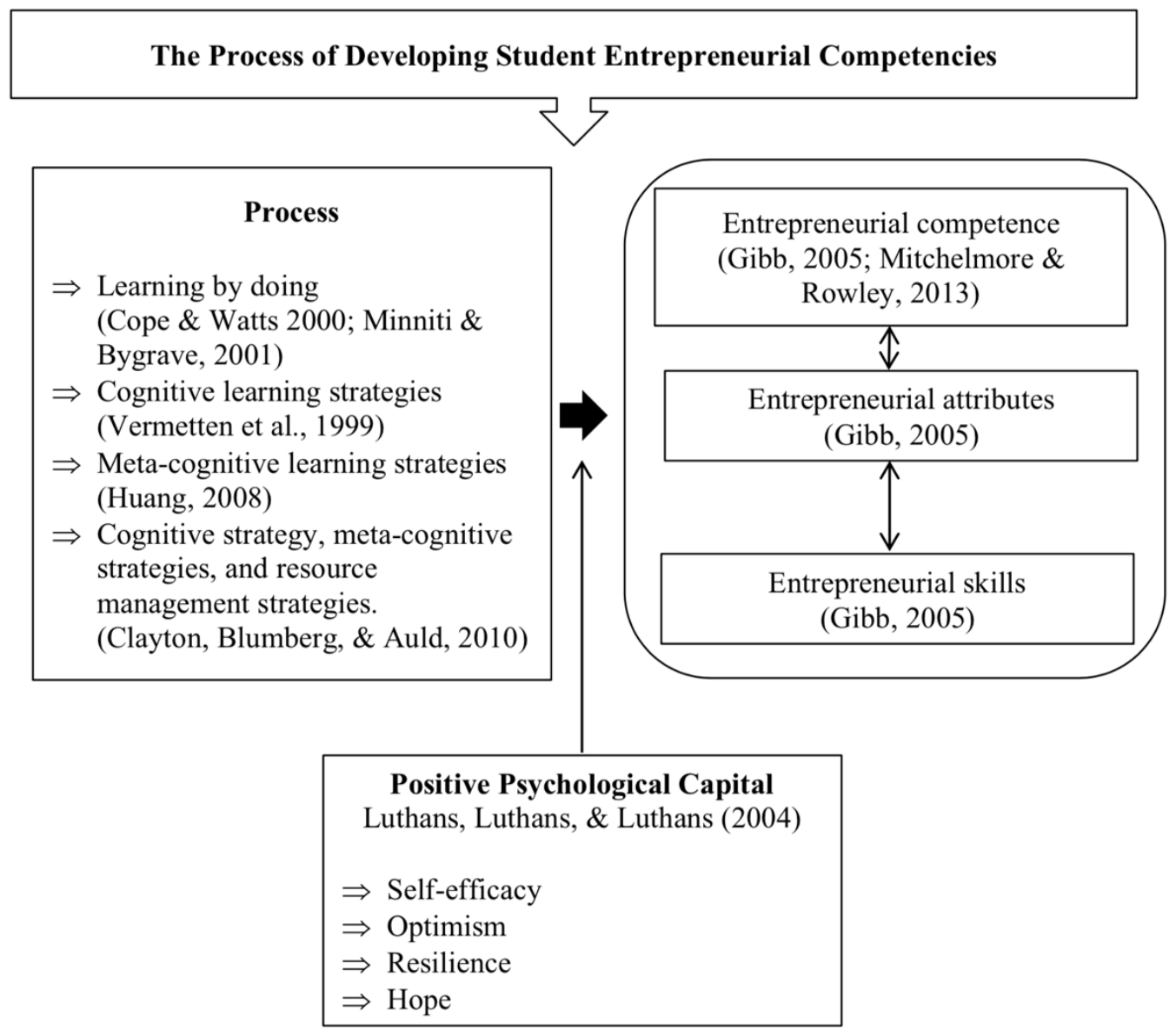

Fig.1. The Conceptual Framework of The Process of Developing Student Entrepreneurial Competencies 


\section{Methods}

This research is included in the type of explanatory research, which is non-experimental in nature and aims to analyze the influence of entrepreneurial learning and positive psychology capital on student entrepreneurial competencies in South Sulawesi Province, using a quantitative approach through parameter testing in answering hypotheses. To get data in accordance with the study design, the closed-ended question type was used. Entrepreneurship learning refers to Clayton, Blumberg, \& Auld (2010) with dimensions of cognitive strategy, meta-cognitive strategy, and resource management strategies, the measuring scale used is ordinal. Positive psychology capital refers to Luthans, Luthans, \& Luthans (2004) with dimensions, namely: self-efficacy, optimism, resilience, and hope, the measurement scale used is ordinal. Measurement of entrepreneurial competencies includes proper identification and niche market definition, development of products or services that are in line with niche markets/product innovation, idea creation, identification of the environment, recognizing and utilizing opportunities, and formulating strategies to take advantage of opportunities (Mitchelmore \& Rowley, 2013), with an ordinal measurement scale.

The population in this study were 345 students who had participated in entrepreneurship education and training in South Sulawesi Province, while the sample size was 201 students who already had and were running a business. Data analysis techniques use statistical testing to verify the various problems presented in the hypothesis, so that generalization can be carried out, and based on path analysis. The purpose of path analysis is to find out the direct and indirect effects of a set of exogenous variables on endogenous variables (Hair et al., 2010). Based on the description, the variables examined in this article can be seen in Table 1.

Table 1. Research Variable

\begin{tabular}{|c|c|c|c|c|}
\hline No. & Variable & Symbol & Dimension & Symbol \\
\hline \multirow{3}{*}{1.} & \multirow{3}{*}{$\begin{array}{l}\text { Entrepreneurship learning } \\
\text { (Clayton, Blumberg, \& Auld, 2010) }\end{array}$} & \multirow{3}{*}{$\mathrm{X}_{1}$} & Cognitive strategy & $\mathrm{X}_{1.1}$ \\
\hline & & & Meta-cognitive strategy & $\mathrm{X}_{1.2}$ \\
\hline & & & Resource management strategies & $\mathrm{X}_{1.3}$ \\
\hline \multirow{4}{*}{2.} & \multirow{4}{*}{$\begin{array}{l}\text { Positive psychology capital } \\
\text { (Luthans, Luthans, \& Luthans, 2004) }\end{array}$} & \multirow{4}{*}{$\mathrm{X}_{2}$} & Self-efficacy & $\mathrm{X}_{2.1}$ \\
\hline & & & Optimism & $\mathrm{X}_{2.2}$ \\
\hline & & & Resilience & $\mathrm{X}_{2.3}$ \\
\hline & & & Hope & $\mathrm{X}_{2.4}$ \\
\hline \multirow{6}{*}{3.} & \multirow{6}{*}{$\begin{array}{l}\text { Entrepreneurial competencies } \\
\text { (Mitchelmore \& Rowley, 2013) }\end{array}$} & \multirow{6}{*}{$\mathrm{Y}_{1}$} & Market identification & $\mathrm{Y}_{1.1}$ \\
\hline & & & Product development and innovation & $\mathrm{Y}_{1.2}$ \\
\hline & & & Idea creation & $\mathrm{Y}_{1.3}$ \\
\hline & & & Identification of the environment & $\mathrm{Y}_{1.4}$ \\
\hline & & & Recognizing and utilizing opportunities & $\mathrm{Y}_{1.5}$ \\
\hline & & & Take advantage of opportunities & $\mathrm{Y}_{1.6}$ \\
\hline
\end{tabular}

\section{Results and discussion}

The results of the instrument validity test indicate that all indicators in the research variable meet the data validity requirements. For more details can be seen in Table 2. 
ENTREPRENEURSHIP AND SUSTAINABILITY ISSUES

ISSN 2345-0282 (online) http://jssidoi.org/jesi/ 2019 Volume 7 Number 1 (September)

http://doi.org/10.9770/jesi.2019.7.1(30)

Table 2. Validity Test

\begin{tabular}{|c|c|c|c|c|}
\hline Variable & Dimension & Indicator & $\mathbf{r}$ & Information \\
\hline \multirow{14}{*}{$\begin{array}{l}\text { Entrepreneurship learning } \\
\left(\mathrm{X}_{1}\right)\end{array}$} & \multirow{6}{*}{ Cognitive strategy $\left(\mathrm{X}_{1.1}\right)$} & $\mathrm{X}_{1.1 .1}$ & 0.821 & Valid \\
\hline & & $\mathrm{X}_{1.1 .2}$ & 0.765 & Valid \\
\hline & & $\mathrm{X}_{1.1 .3}$ & 0.774 & Valid \\
\hline & & $\mathrm{X}_{1.1 .4}$ & 0.689 & Valid \\
\hline & & $\mathrm{X}_{1.1 .5}$ & 0.822 & Valid \\
\hline & & $\mathrm{X}_{1.1 .6}$ & 0.756 & Valid \\
\hline & \multirow{4}{*}{ Meta-cognitive strategy $\left(\mathrm{X}_{1.2}\right)$} & $\mathrm{X}_{1.2 .1}$ & 0.875 & Valid \\
\hline & & $\mathrm{X}_{1.2 .2}$ & 0.875 & Valid \\
\hline & & $\mathrm{X}_{1.2 .3}$ & 0.885 & Valid \\
\hline & & $\mathrm{X}_{1.2 .4}$ & 0.768 & Valid \\
\hline & \multirow{4}{*}{ Resource management strategies $\left(\mathrm{X}_{1.3}\right)$} & $\mathrm{X}_{1.3 .1}$ & 0.829 & Valid \\
\hline & & $\mathrm{X}_{1.3 .2}$ & 0.789 & Valid \\
\hline & & $\mathrm{X}_{1.3 .3}$ & 0.772 & Valid \\
\hline & & $\mathrm{X}_{1.3 .4}$ & 0.731 & Valid \\
\hline \multirow{15}{*}{$\begin{array}{l}\text { Positive psychology capital } \\
\left(\mathrm{X}_{2}\right)\end{array}$} & \multirow{3}{*}{ Self-efficacy $\left(\mathrm{X}_{2.1}\right)$} & $\mathrm{X}_{2.1 .1}$ & 0.845 & Valid \\
\hline & & $\mathrm{X}_{2.1 .2}$ & 0.887 & Valid \\
\hline & & $\mathrm{X}_{2.1 .3}$ & 0.756 & Valid \\
\hline & \multirow{4}{*}{$\operatorname{Optimism}\left(\mathrm{X}_{2.2}\right)$} & $\mathrm{X}_{2.2 .1}$ & 0.865 & Valid \\
\hline & & $\mathrm{X}_{2.2 .2}$ & 0.872 & Valid \\
\hline & & $\mathrm{X}_{2.2 .3}$ & 0.743 & Valid \\
\hline & & $\mathrm{X}_{2.2 .4}$ & 0.882 & Valid \\
\hline & \multirow{4}{*}{ Resilience $\left(\mathrm{X}_{2.3}\right)$} & $\mathrm{X}_{2.3 .1}$ & 0.764 & Valid \\
\hline & & $\mathrm{X}_{2.3 .2}$ & 0.751 & Valid \\
\hline & & $\mathrm{X}_{2.3 .3}$ & 0.890 & Valid \\
\hline & & $\mathrm{X}_{2.3 .4}$ & 0.746 & Valid \\
\hline & \multirow{4}{*}{ Hope $\left(\mathrm{X}_{2.4}\right)$} & $\mathrm{X}_{2.4 .1}$ & 0.825 & Valid \\
\hline & & $\mathrm{X}_{2.4 .2}$ & 0.713 & Valid \\
\hline & & $\mathrm{X}_{2.4 .3}$ & 0.734 & Valid \\
\hline & & $\mathrm{X}_{2.4 .4}$ & 0.862 & Valid \\
\hline \multirow{21}{*}{$\begin{array}{l}\text { Entrepreneurial competencies } \\
\left(\mathrm{Y}_{1}\right)\end{array}$} & \multirow{3}{*}{ Market identification $\left(\mathrm{Y}_{1.1}\right)$} & $Y_{1.1 .1}$ & 0.781 & Valid \\
\hline & & $\mathrm{Y}_{1.1 .2}$ & 0.881 & Valid \\
\hline & & $Y_{1.1 .3}$ & 0.893 & Valid \\
\hline & \multirow{4}{*}{ Product development and innovation $\left(\mathrm{Y}_{1.2}\right)$} & $\mathrm{Y}_{1.2 .1}$ & 0.821 & Valid \\
\hline & & $Y_{1.2 .2}$ & 0.774 & Valid \\
\hline & & $\mathrm{Y}_{1.2 .3}$ & 0.725 & Valid \\
\hline & & $Y_{1.2 .4}$ & 0.851 & Valid \\
\hline & \multirow{3}{*}{ Idea creation $\left(\mathrm{Y}_{1.3}\right)$} & $Y_{1.3 .1}$ & 0.763 & Valid \\
\hline & & $\mathrm{Y}_{1.3 .2}$ & 0.852 & Valid \\
\hline & & $Y_{1.3 .3}$ & 0.742 & Valid \\
\hline & \multirow{3}{*}{ Identification of the environment ( $\left.\mathrm{Y}_{1.4}\right)$} & $\mathrm{Y}_{1.4 .1}$ & 0.842 & Valid \\
\hline & & $Y_{1.4 .2}$ & 0.755 & Valid \\
\hline & & $Y_{1.4 .3}$ & 0.791 & Valid \\
\hline & \multirow{4}{*}{ Recognizing and utilizing opportunities ( $\left.\mathrm{Y}_{1.5}\right)$} & $Y_{1.5 .1}$ & 0.765 & Valid \\
\hline & & $Y_{1.5 .2}$ & 0.882 & Valid \\
\hline & & $\mathrm{Y}_{1.5 .3}$ & 0.761 & Valid \\
\hline & & $Y_{1.5 .4}$ & 0.821 & Valid \\
\hline & \multirow{4}{*}{ Take advantage of opportunities $\left(\mathrm{Y}_{1.6}\right)$} & $Y_{1.6 .1}$ & 0.723 & Valid \\
\hline & & $Y_{1.6 .2}$ & 0.831 & Valid \\
\hline & & $Y_{1.6 .3}$ & 0.754 & Valid \\
\hline & & $Y_{1.6 .4}$ & 0.771 & Valid \\
\hline
\end{tabular}

Source: Computed by authors 
The results of the validity test in Table 2 show that all indicators in entrepreneurial learning variables, positive psychology capital, and entrepreneurial competence have a pearson correlation (correlation coefficient) that is greater than 0.30 , so that all of these indicators have met the data validity requirements. After the validity test is done, then the instrument reliability test is carried out as shown in Table 3.

Table 3. Reliability Test

\begin{tabular}{|c|l|c|c|}
\hline No. & \multicolumn{1}{|c|}{ Variable } & Cronbach's Alpha & Information \\
\hline 1. & Entrepreneurship learning $\left(\mathrm{X}_{1}\right)$ & 0.811 & Reliable \\
\hline 2. & Positive psychology capital $\left(\mathrm{X}_{2}\right)$ & 0.790 & Reliable \\
\hline 3. & Entrepreneurial competencies $(\mathrm{Y})$ & 0.874 & Reliable \\
\hline
\end{tabular}

Source: Computed by authors

This study examines the direct and indirect effects of entrepreneurial learning on the formation of positive psychology capital, and explains the direct and indirect effects of entrepreneurial learning and positive psychology capital on student entrepreneurial competencies in South Sulawesi Province. Summary of research results can be seen in Table 4.

Table 4. Path Analysis Coefficient(s)

\begin{tabular}{|c|c|c|c|}
\hline \multicolumn{4}{|c|}{ Direct Effect } \\
\hline $\begin{array}{l}\text { Path Analysis } \\
\end{array}$ & Path Coefficient & Prob. & Result \\
\hline Entrepreneurship Learning $\rightarrow$ Positive Psychological Capital & 0.887 & 0.000 & Significant \\
\hline Entrepreneurship Learning $\rightarrow$ Entrepreneur Competence & 0.613 & 0.001 & Significant \\
\hline Positive Psychological Capital $\rightarrow$ Entrepreneur Competence & 0.754 & 0.015 & Significant \\
\hline \multicolumn{4}{|l|}{ Indirect Effect } \\
\hline Indirect Path & \multicolumn{3}{|c|}{ Path Coefficient } \\
\hline $\begin{array}{l}\text { Entrepreneurship Learning } \rightarrow \text { Positive Psychological Capital } \rightarrow \\
\text { Entrepreneur Competence }\end{array}$ & \multicolumn{3}{|c|}{$0.887 \times 0.754=0.668$} \\
\hline
\end{tabular}

Source: Computed by authors

Based on the results of data processing, the entrepreneurial learning path coefficient for positive psychological capital formation is 0.887 , indicating that the influence of entrepreneurial learning on positive psychology capital formation is 0.887 with a probability value of 0.000 . The results of this analysis indicate that entrepreneurship learning has a significant effect on the formation of positive psychology capital of students who become entrepreneurs. The coefficient of entrepreneurship learning pathway towards entrepreneurial competence is equal to 0.613 indicating that the influence of entrepreneurial learning on entrepreneurial competencies is 0.613 . The probability value of entrepreneurship learning on entrepreneurial competencies is 0.001 . The results of this analysis indicate that entrepreneurial learning has a significant effect on student entrepreneurial competencies that become entrepreneurs. The positive psychology capital path coefficient on entrepreneurial competence is 0.754 , indicating that the positive psychological capital effect on entrepreneurial competency is 0.754 . The probability value of family capital on business performance is 0.015 , so the results of this analysis indicate that positive psychological capital has a significant effect on student entrepreneurial competencies that become entrepreneurs. The indirect coefficient of entrepreneurship learning on entrepreneurial competence through positive psychology capital is 0.668 , indicating that the coefficient of entrepreneurial learning pathways towards entrepreneurial competence through positive psychological capital is 0.668 . 


\section{ENTREPRENEURSHIP AND SUSTAINABILITY ISSUES}

ISSN 2345-0282 (online) http://jssidoi.org/jesi/

2019 Volume 7 Number 1 (September)

http://doi.org/10.9770/jesi.2019.7.1(30)

The findings of this study indicate that entrepreneurial learning influences the formation of positive psychology capital. This shows that entrepreneurial learning determines the level of formation of positive psychology capital (Sarasvathy, 2004). Entrepreneurship learning that is applied makes students learn from direct experience and other experiences around the campus environment. Positive psychological capital formation is the result of high learning intensity (Cope, 2003).

The test results in this study indicate that entrepreneurial learning influences entrepreneurial competencies. These results indicate that applied entrepreneurship learning has been able to cover the realm of skills. There are 3 approaches to entrepreneurship learning, which include entrepreneurial learning by emphasizing theoretical study, work-oriented learning, this learning encourages students to practice becoming entrepreneurs, fosters students' interest in becoming entrepreneurs with knowledge and skills in the field of entrepreneurship, and learning through entrepreneurial activities, this learning invites students to learn to be directly involved in business activities (O'Connor, 2013).

The findings of this study indicate that student entrepreneurship competencies are supported by appropriate learning processes within the institution. The curriculum in the institution contains a sequence of courses related to the formation of student entrepreneurial competencies that are in accordance with the cognitive, affective, and psychomotor levels of students. This is tailored to the expected competencies through a systematic process. These findings are in accordance with the findings of Markowska (2011) who suggested that learning entrepreneurship should be the main vehicle for the development of student entrepreneurial competencies. The research findings also show that universities have used learning with experience as one of the main methods of delivering entrepreneurial material, so that izn every learning the weight between knowledge and skills through practice is increasingly dominant in entrepreneurship learning. Makassar State University, as one of the research locations, has provided a center for entrepreneurship, external/internal funding for students who want entrepreneurship, community services and guest lectures, and business incubators. This shows that entrepreneurship learning is also focused on aspects of learning while working or direct observation.

Another finding in this study shows that positive psychological capital has a significant effect on entrepreneurial competence and there is an influence of entrepreneurial learning on entrepreneurial competence through mediating the formation of positive psychology capital. Entrepreneurial success is a series of positive results from the utilization of internal forces contained within humans (Seligman \& Csikszentmihalyi, 2000). Entrepreneurship views success not only financially but also psychologically (Gorgievski et al., 2011). For entrepreneurs, nonfinancial incentives are more satisfying, while financial benefits do not always bring the greatest satisfaction (Alstete, 2008; Zainal et al., 2018). Meanwhile, the career success literature highlights that people are more appreciative of personal success than objective performance measures, given their full commitment to their work (Poon, 2005). In other words, successful entrepreneurs often feel more satisfied after all the difficulties and are far more satisfied after sharing a lot of money or wealth with the community in the form of charity, donations, sponsors and at the same time, transforming gratitude to the city for success (Csikzentmihalyi, 2000). Thus, entrepreneurial success is highlighted to comprise not only financial benefits but also measures of psychological success, such as satisfaction, gratitude, and readiness (Tang et al., 2010).

The findings of this study indicate that the most dominant dimension of positive psychology capital held by students is optimism. Optimism is a way of interpreting positive events as a matter that occurs as a result of self, is permanent, and can occur in various situations; and interpret negative events as things that occur due to things outside ourselves, are temporary, and only occur in certain situations (Luthans et al., 2007). Optimism is also interpreted as a hope for a positive and open future for settled self-development (Avey, Richard, Luthans, Mhatre, 2011). 


\section{ENTREPRENEURSHIP AND SUSTAINABILITY ISSUES}

ISSN 2345-0282 (online) http://jssidoi.org/jesi/ 2019 Volume 7 Number 1 (September) http://doi.org/10.9770/jesi.2019.7.1(30)

Optimistic students will be more realistic and flexible. Because, optimism in positive psychology capital is not only described as positive feelings but also a strong learning in terms of self discipline, analysis of past mistakes, and planning to prevent the occurrence of bad things. Students with high optimism will be able to feel cognitive and emotional implications when they get success (Luthans et al., 2007).

\section{Conclusions}

The results of this study indicate that entrepreneurial learning has a significant effect on the formation of positive psychology capital. Other findings show that positive psychology capital has a significant influence on entrepreneurial competence. The results of path analysis show that entrepreneurial learning has a significant effect on entrepreneurial competence through the mediation of positive psychology capital. The research findings have implications for the importance of entrepreneurial learning in higher education, both through education and training, to form positive psychological capital that can support the formation of entrepreneurial competencies.

The findings of this study are able to provide information on the importance of psychological factors in forming entrepreneurial competencies, so that entrepreneurship learning at the tertiary level must be designed to balance cognitive, affective, and psychomotor, especially in the affective aspect, positive psychology capital formation is very important because of the formation of entrepreneurial competencies very much determined by positive psychology capital. Future research is expected to conduct research by looking for other psychological factors that can shape student entrepreneurial competencies.

This research is inseparable from several limitations. The first limitation is, this study only managed to identify entrepreneurship learning models based on student perceptions, so that in the future it is hoped that the entrepreneurship learning model that has been identified can be developed in the form of development research. The second limitation is that this study only measures positive psychology capital and student entrepreneurship skills based on the perceptions of respondents who are still students, so that in the future this research can be developed to measure positive psychology capital and entrepreneurship skills of students who have completed college education and decide to become an entrepreneur.

\section{References}

Alstete, J.W. (2008). Aspects of entrepreneurial success. Journal of Small Business and Enterprise Development 15(3): 584-594. https://doi.org/10.1108/14626000810892364

Amorós, J. E., Bosma, N. (2014). Global Entrepreneurship Monitor 2013 Global Report Fifteen Years of Assessing Entrepreneurship Across The Globe. Global Entrepreneurship Research Association (GERA). https://www.gemconsortium.org/report

Avey, J., Richard, R.J., Luthans, F., \& Mhatre, F.H. (2011). Meta-analysis of the impact of positive psychological capital on employee attitudes, behavior, and performance. Human Resource Development Quarterly, 22 (2), 127-152. https://doi.org/10.1002/hrdq.20070

Azis, M., Haeruddin, M., \& Azis, F. (2018). Entrepreneurship education and career intention: The Perks of being a woman student. Journal of Entrepreneurship Education, 21(1), 1-10. https://www.abacademies.org/articles/Entrepreneurship-education-and-career-intention-15282651-21-1-145.pdf

Baron, R. A., Franklin, R. J. \& Hmieleski, K. M. (2013). Why entrepreneurs often experience low, not high, levels of stress the joint effects of selection and psychological capital. Journal of Management, 0149206313495411. https://doi.org/10.1177/0149206313495411

Baubonienè, Ž., Hahn, K. H., Puksas, A., Malinauskienė, E. (2018). Factors influencing student entrepreneurship intentions: the case of Lithuanian and South Korean universities. Entrepreneurship and Sustainability Issues, 6(2), 854-871. http://doi.org/10.9770/jesi.2018.6.2(26) 


\section{ENTREPRENEURSHIP AND SUSTAINABILITY ISSUES}

ISSN 2345-0282 (online) http://jssidoi.org/jesi/ 2019 Volume 7 Number 1 (September) http://doi.org/10.9770/jesi.2019.7.1(30)

Biavaschi, C., Eichhorst, W., Giulietti, C., Kendzia, M.J., Muravyev, A., Pieters, J., Rodriguez-Planas, N., Schmidl, R., \& Zimmermann, K.F. (2012). Youth unemployment and vocational training. Bonn: Germany. http://ftp.iza.org/dp6890.pdf

Ciavarella, M. A., Buchholtz, A. L., Riordan, C. M., Gatewood, R. D., \& Stokes, G. S. (2004). The big five and venture survival: is there a link? Journal of Business Venturing, 19(4), 465-483. http://www.sciencedirect.com/science/article/pii/S0883-9026(03)00093-4

Clayton, K., Blumberg, F.C., \& Auld, D.P. (2010). The relationship between motivation, learning strategies and choice of environment whether traditional or including an online component. BJET, 41, 349-364. https://doi.org/10.1111/j.1467-8535.2009.00993.x

Cope, J., Watts, G. (2000). Learning by doing - An exploration of experience, critical incidents and reflection in entrepreneurial learning. International Journal of Entrepreneurial Behavior \& Research, 6(3), 104-124. https://doi.org/10.1108/13552550010346208

Cope, J. (2003). Entrepreneurial Learning and Critical Reflection: Discontinuous Events as Triggers for 'Higher-level' Learning. Management Learning 34(4), 429-450. https://doi.org/10.1177/1350507603039067

Csikzentmihalyi, M. (2003). Good business: leadership, flow, and the making of meaning. New York: Penguin Group. https://epdf.pub/good-business-leadership-flow-and-the-making-of-meaning30260.html

Ernst \& Young. (2011). Nature or nurture? Decoding the DNA of the entrepreneur. Ernst \& Young Global Limited. https://www.ey.com/Publication/vwLUAssets/ey-nature-or-nurture/\$FILE/ey-nature-or-nurture.pdf

Ernst \& Young. (2012). Avoiding a lost generation: young entrepreneurs identify five imperatives for action. Ernst \& Young Global Limited.

https://www.ey.com/Publication/vwLUAssets/Avoiding_a_lost_generation_June_2013/\$FILE/Avoiding_a_lost_generation_LoRes_FINAL . $\mathrm{pdf}$

Essia, U. (2012). Entrepreneurial culturing of formal education programmes in Nigeria. Journal of Sustainable Society, 1(2), 52-62. http://www.paidafrica.org/paidwa/images/data/ENTREPRENEURIAL_CULTURING_OF_FORMAL_EDUCATION_PROGRAMMES_I $\underline{\text { N NIGERIA.pdf }}$

Frese, M., Bausch, A., Schmidt, P., Strauch, A. \& Kabst, R. (2012). Evidence based entrepreneurship: cumulative science, action principles, and bridging the gap between science and practice. Foundations and Trends in Entrepreneurship, 8. https://www.cebma.org/wpcontent/uploads/Frese-et-al-EBE-Trends-in-Entrepr.pdf

Galloway, L., S. Kelly, dan W. Keogh. (2006). Identifying entrepreneurial potential in students. Working Paper. No. 6, National Council for Graduate Entrepreneurship. http://gees.pbworks.com/f/entrepreneurialpotential.pdf

Gibb, A.A. (2005). Towards the Entrepreneurial University. Entrepreneurship Education as a lever for change. A Policy Paper for the National Council for Graduate Entrepreneurship (NCGE). UK: National Council for Graduate Entrepreneurship. http://blog.ub.ac.id/yogidwiatmoko/files/2012/12/gibb_hannon.pdf

Girdzijauskaite, E., Radzeviciene, A., Jakubavicius, A. 2019. Impact of international branch campus KPIs on the university competitiveness: FARE method. Insights into Regional Development, 1(2), 171-180. https://doi.org/10.9770/ird.2019.1.2(7)

Gorgievski, M.J., Bakker, A. \& Schaufeli, W.B. (2011). Work engagement and workaholism: comparing the self- employed and salaried employees. The Journal of Positive Psychology, 5(1), 83-96. https://doi.org/10.1080/17439760903509606

Grubor, A. (2013). Marketing aspects of socially responsible business. Strategic Management, 18(3), 030-036. https://bib.irb.hr/datoteka/650745.SM2013_3.pdf - page=32

Haeruddin, M., \& Natsir, U. D. (2016). The cat's in the cradle: 5 personality types' influence on work-family conflict of nurses. Economics \& Sociology, 9(3), 99-110. 10.14254/2071-789X.2016/9-3/9

Haeruddin, M. I. M., Pick, D., \& Thein, H. H. (in press). Resistance and compliance in women's academic identity work in the Global South. Higher Education Quarterly. https://doi.org/10.1111/hequ.12204 


\section{ENTREPRENEURSHIP AND SUSTAINABILITY ISSUES}

ISSN 2345-0282 (online) http://jssidoi.org/jesi/ 2019 Volume 7 Number 1 (September) http://doi.org/10.9770/jesi.2019.7.1(30)

Hair, Joseph F., et al. (2010). Multivariate data analysis, 7th Edition. New York: Prentice Hall International, Inc. https://is.muni.cz/el/1423/podzim2017/PSY028/um/ Hair - Multivariate data analysis 7th revised.pdf

Hasan, Muhammad, dan Azis, Muhammad. (2018). Pembangunan ekonomi \& pemberdayaan masyarakat: strategi pembangunan manusia dalam perspektif ekonomi lokal. Makassar: CV. Nur Lina Bekerjasama dengan Pustaka Taman Ilmu. http://eprints.unm.ac.id/10706/

Hegarty, C. (2006). It's not an exact science: teaching entrepreneurship in Northern Ireland. Journal of Education + Training, 48(5), 322335, https://doi.org/10.1108/00400910610677036

Henderson, R., \& Robertson, M. (2000). Who wants to be an entrepreneur? Young adult attitudes to entrepreneurship as a career. Career Development International, 5(6), 236-245. https://doi.org/10.1108/00400919910279973

Hmieleski, K. M. \& Carr, J. C. (2008). The relationship between entrepreneur psychological capital and new venture performance. Frontiers of Entrepreneurship Research, 28(4). http://digitalknowledge.babson.edu/fer/vol28/iss4/1

Huang, S. (2008). Assessing motivation and learning strategies using the motivated strategies for learning questionnaire in a foreign language learning context. Social Behavior and Personality, 36(4), 529-534. https://doi.org/10.2224/sbp.2008.36.4.529

Jensen, S. M. \& Luthans, F. (2006). Relationship between entrepreneurs' psychological capital and their authentic leadership. Journal of Managerial Issues, 18(2), 254-273. https://www.jstor.org/stable/40604537?seq=1 - page_scan_tab_contents

Krueger, N. (1993). The impact of prior entrepreneurial exposure on perceptions of new venture feasibility and desirability. Entrepreneurship Theory and Practice, 18(1), 5-21. https://doi.org/10.1177/104225879301800101

Luthans, F., Luthans, K.W. \& Luthans, B.C. (2004). Positive psychological capital: beyond human and social capital. Business Horizon, 47(1), 45-50. http://chur.chu.edu.tw/bitstream/987654321/39064/2/Positive+psychological+capital_A_12_2.pdf

Luthans, F., Avolio, B.J., Avey, J.B. \& Norman, S.M. (2007). Positive psychological capital: measurement and relationship with performance and satisfaction. Personnel Psychology, 60(3), 541-572. http://dx.doi.org/10.1111/j.1744-6570.2007.00083.x

Marlow, S., \& McAdam, M. (2011). Analyzing the influence of gender upon high technology venturing within the context of business incubation. Entrepreneurship Theory and Practice, 36(4), 655-676. https://doi.org/10.1111/j.1540-6520.2010.00431.x

Matthews, C. H., \& Moser, S. B. (1996). A longitudinal investigation of the impact of family background and gender on interest in small firm ownership. Journal of Small Business https://www.researchgate.net/profile/Charles_Matthews3/publication/244958069_A_Longitudinal_Investigation_of_the_Impact_of_Famil $\mathrm{y}$ Background and Gender on Interest in Small Firm Ownership/links/54ac434f0cf23c69a2b79841/A-Longitudinal-Investigation-of$\underline{\text { the-Impact-of-Family-Background-and-Gender-on-Interest-in-Small-Firm-Ownership.pdf }}$

Minniti, M., \& Bygrave, W. (2001). A dynamic model of entrepreneurial learning. Entrepreneurship Theory and Practice, 25(3), 5-16. https://doi.org/10.1177/104225870102500301

Mitchelmore, S. and Rowley, J., (2013). Entrepreneurial competencies of women entrepreneurs pursuing business growth. Journal of Small Business and Enterprise Development, 20(1), 125-142. https://doi.org/10.1108/14626001311298448

Morris, M.H., Webb, J.W., Fu, J. and Singhal, S. (2013). A competency-based perspective on entrepreneurship education: conceptual and empirical insights. Journal of Small Business Management, 51(3), 352-369. https://doi.org/10.1111/jsbm.12023

Musa, C. I. and Hasan, M. (2018). The influence of social, economic, and demographic characteristic on working hours of micro, small, and medium enterprises (MSMEs) in Makassar City. Journal of Physics: Conf. Series 1028 (2018) 012181. https://iopscience.iop.org/article/10.1088/1742-6596/1028/1/012181

Musa, M. I., Haeruddin, M. I. W., \& Haeruddin, M. (2018). Customers' repurchase decision in the culinary industry: Do the Big-Five personality types matter?. Journal of Business and Retail Management Research, 13(1), 131-137. 10.24052/jbrmr/v13is01/art-13 


\section{ENTREPRENEURSHIP AND SUSTAINABILITY ISSUES}

ISSN 2345-0282 (online) http://jssidoi.org/jesi/ 2019 Volume 7 Number 1 (September) http://doi.org/10.9770/jesi.2019.7.1(30)

Newman, A., Schwarz, S. \& Borgia, D. (2013). How does micro firm enhance entrepreneurial outcomes in emerging economies? The mediating mechanism of psychological and social capital. International Small Business Journal 32(2), 158-179. $\underline{\text { https://doi.org/10.1177/0266242613485611 }}$

O’Connor, A. (2013). A conceptual framework for entrepreneurship education policy: meeting government and economic purposes. Journal of Business Venturing, 24(1), 546-563. http://www.sciencedirect.com/science/article/pii/S0883902612000857

Poon, J.M.L. (2005). Career commitment and career success: moderating role of emotional perception. Career Development International 9(4), 374-390. https://doi.org/10.1108/13620430410544337

Sarasvathy, S.D. (2004). The questions we ask and the question we care about: reformulating some problems in entrepreneurship research. Journal of Business Venturing 19(5), 707-717. https://www.effectuation.org/wp-content/uploads/2017/05/2004-JBV-Questions-1.pdf

Seligman, M.E.P. \& Csikszentmihalyi, M. (2000). Positive psychology. American Psychologist 55(1), 5-14. http://dx.doi.org/10.1037/0003-066X.55.1.5

Tang, J., Kacmar, K.M. \& Busenitz, L. (2010). Entrepreneurial alertness in the pursuit of new opportunities. Journal of Business Venturing, 27, 77-94. https://doi.org/10.1016/i.jbusvent.2010.07.001

Vermetten, Y.J., Lodewijks, H.G., \& Vermunt, J.D. (1999). Consistency and variability of learning strategies in different university courses. Higher Education, 37(1), 1-21. https://doi.org/10.1023/A:1003573727713

Zainal, H., Parinsi, K.W., Hasan, M., Said, F., and Akib, H. (2018). The Influence of Strategic Assets and Market Orientation to the Performance of Family Business in Makassar City, Indonesia. Academy of Strategic Management Journal, 17(6). https://www.abacademies.org/articles/The-influence-of-strategic-assets-and-market-orientation-to-the-performance-1939-6104-17-6$\underline{308 . p d f}$

Zhao, H., Seibert, S. E., \& Hills, G. E. (2005). The mediating role of self-efficacy in the development of entrepreneurial intentions. Journal of Applied Psychology, 90(6), 1265-1272. http://dx.doi.org/10.1037/0021-9010.90.6.1265

\section{Aknowledgements}

We would like to thank the Directorate of Higher Education, Ministry of Research, Technology and Higher Education, the Republic of Indonesia for their financial support of this research. We appreciate the Research Institution of Universitas Negeri Makassar (UNM), and to anonymous reviewers for excellent comments and suggestions for this paper.

Muhammad HASAN is a Lecturer in Department of Economics Education, Faculty of Economics, Universitas Negeri Makassar. His research fields include entrepreneurship, economic education, informal education, economic literacy, and knowledge transfer.

ORCID ID: https://orcid.org/0000-0003-1112-2110

includes entrepreneurship and economic education

ORCID ID: https://orcid.org/0000-0002-0819-3471 


\section{ENTREPRENEURSHIP AND SUSTAINABILITY ISSUES}

ISSN 2345-0282 (online) http://jssidoi.org/jesi/ 2019 Volume 7 Number 1 (September)

http://doi.org/10.9770/jesi.2019.7.1(30)

NURJANNA is a Lecturer in Department of Management, STIE Tri Dharma Nusantara Makassar. His research fields include entrepreneurship, management, and financial management.

ORCID ID: $\underline{\text { https://orcid.org/0000-0002-6083-1215 }}$

Feliks Arfid GUAMPE is a Lecturer in Department of Economics Development, Universitas Kristen Tentena. His field of research studies includes the economics of entrepreneurship, management, and economic education.

ORCID ID: https://orcid.org/0000-0003-0597-9740

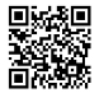

GEMPITA is a Lecturer in Department of Management, STIE Yapman Majene. His field of research studies includes the economics of entrepreneurship, management, and economic education

ORCID ID: https://orcid.org/0000-0003-3248-0881

Makassar. His field of research includes entrepreneurship, agribusiness, and agricultural economics.

ORCID ID: https://orcid.org/0000-0002-2128-5952

Register for an ORCID ID:

https://orcid.org/register

Copyright (C) 2019 by author(s) and VsI Entrepreneurship and Sustainability Center

This work is licensed under the Creative Commons Attribution International License (CC BY).

http://creativecommons.org/licenses/by/4.0/

(c) (i) Open Access 